\title{
PENGEMBANGAN DINO PARK 3D BERBASIS VIRTUAL REALITY MENGGUNAKAN GOOGLE VR SDK
}

\author{
Moch. Kholil ${ }^{1}$, Rafika Akhsani \\ ${ }^{1,2}$ Akademi Komunitas Negeri Putra Sang Fajar Blitar \\ ${ }^{1}$ moch.kholi189@gmail.com, ${ }^{2}$ achsany@ gmail.com
}

\begin{abstract}
Abstrak
Virtual Reality adalah sebuah teknologi yang membuat pengguna atau user dapat berinteraksi dengan lingkungan yang ada dalam dunia maya dan disimulasikan menggunaan komputer, sehingga pengguna merasa berada di dalam lingkungan tersebut. Pemanfaatan Virtual Reality juga sangat membantu dalam bidang pendidikan dan pariwisata. Sebagai salah satu bentuk pemanfaatannya adalah menyajikan pengenalan Dinosaurus dalam bentuk 3D, sehingga pengguna dapat mengenal berbagai macam Dinosaurus dan berinteraksi dengan lingkungan di dunia maya.

Metode pengembangan VRDino Park 3D yang mengacu pada kerangka kerja Multimedia Development Life Cycle (MDLC) framework dengan implementasi model prototype yang terdiri dari 6 (enam) tahapan mulai dari Concept, Design, Material Collecting, Assembly, Testing, dan Distribution dan menggunakan Google VR SDK dengan melakukan pengujian dan pengisian kuisioner terhadap 34 siswa jurusan Teknik Komputer dan Jaringan kelas 10 SMK Islam Blitar kelas 10 jurusan Teknik Komputer dan Jaringan menghasilkan nilai rata-rata kesesuaian program dan tampilan Virtual Reality $100 \%$.
\end{abstract}

Kata kunci : Virtual Reality, VRDino Park 3D, MDLC, Google VR SDK

\section{Pendahuluan}

Perkembangan teknologi saat ini mengalami peningkatan yang sangat pesat. Teknologi terus berkembang seiring dengan banyaknya pekerjaan manusia guna membantu menyelesaikan pekerjaan dalam berbagai bidang sehingga menjadi semakin optimal. Salah satu tren teknologi yang menarik dan berkembang adalah teknologi Virtual Reality atau biasa disingkat dengan VR. Virtual Reality bermula dari sebuah prototype dari visi yang dibangun oleh Morton Heilig pata tahun 1962 yang bernama Senosorama dengan maksud untuk menghadirkan pengalaman menonton film agar tampak nyata dengan melibatkan berbagai indra berupa indra penglihatan, pendengaran, penciuman, dan sentuhan.

Virtual Reality adalah sebuah teknologi yang membuat pengguna atau user dapat berinteraksi dengan lingkungan yang ada dalam dunia maya dan disimulasikan menggunaan komputer, sehingga pengguna merasa berada di dalam lingkungan tersebut (Kresna, 2016). Teknologi Virtual Reality telah banyak diterapkan dibeberapa sector industri seperti kedokteran, penerbangan, pendidikan, arsitek, militer, hiburan, pariwisata dan lain sebagainya. Virtual Reality sangat membantu dalam mensimulasikan sesuatu yang sulit untuk dihadirkan secara langsung dalam dunia nyata. Seperti halnya untuk bidang militer, Virtual Reality bisa menghadirkan simulasi perang secara virtual tanpa perlu menerjunkan langsung para tentara ke medan perang. Para tentara bisa merasakan sensasi berada di medan perang secara nyata dengan Virtual Reality.

Pemanfaatan Virtual Reality juga sangat membantu dalam bidang pendidikan dan pariwisata. Sebagai contoh pada penerapan teknologi virtual reality untuk media informasi kampus (Herman, 2018). Sebagai salah satu bentuk pemanfaatannya dalam penelitian ini adalah menyajikan pengenalan Dinosaurus dalam bentuk 3D, sehingga pengguna dapat mengenal berbagai macam Dinosaurus dan berinteraksi dengan lingkungan di dunia maya. Berdasarkan dari permasalahan tersebut penelitian ini bertujuan untuk mengembangkan Dino Park 3D Berbasis Virtual Realtiy menggunakan Google Virtual Reality.

\section{Tinjauan Pustaka}

\subsection{Virtual Reality}

Virtual Reality adalah real time grafis interaktif dengan model tiga dimensi, dikombinasikan dengan teknologi layar yang dapat memberikan pengalaman pada pengguna seperti masuk ke dalam dunia virtual dan dapat memanipulasi secara langsung (Fuch \& Bishop, 1992). Selain itu, Virtual Reality adalah bentuk teknologi yang membuat komputer menghasilkan dunia atau lingkungan imersif di mana manusia bisa menjelajah dan berinteraksi. Virtual reality 
menghasilkan lingkungan yang disimulasikan mirip seperti dunia nyata yang dibuat dengan tujuan untuk menghasilkan pengalaman yang menyamai dengan dunia nyata. Di dalam suatu Virtual Reality, pengguna dapat menjelajahi dunia virtual tersebut dan terkadang juga dapat berinteraksi dengan objek di dalam dunia virtual tersebut.

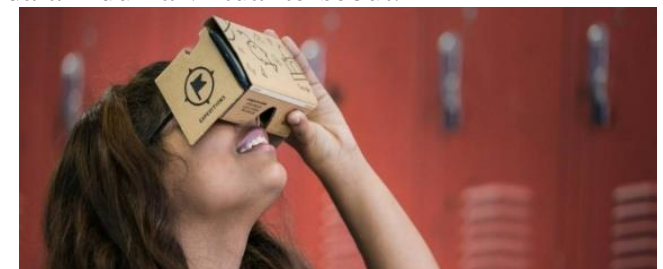

Gambar 1. Virtual Reality sumber: codepolitan.com

Sumber: https://www.codepolitan.com

Kelebihan utama dari Virtual Reality adalah pengalaman yang membuat user merasakan sensasi dunia nyata dalam dunia maya. Bahkan perkembangan teknologi Virtual Reality saat ini memungkinkan tidak hanya indra penglihatan dan pendengaran saja yang bisa merasakan sensasi nyata dari dunia maya dari Virtual Reality, namun juga indra yang lainnya.

Untuk memunculkan sensasi nyata dari Virtual Reality diperlukan perangkat pendukung. Perangkat yang digunakan untuk mendukung teknologi tersebut biasanya berupa helm, walker, headset, suit dan sarung tangan (glove). Perangkatperangkat tersebut bertujuan untuk melibatkan sebanyak mungkin indra yang dimiliki manusia. Tentunya dengan banyak indra yang telibat dalam Virtual Reality akan berbanding lurus dengan tingkat sensasi dunia nyata dari dunia virtual yang dimunculkan. Paling tidak dibutuhkan sebuah headset yang dipasang pada smartphone yang mendukung VR untuk bisa merasakan sensasi Virtual Reallity.

Terdapat empat elemen penting dalam Virtual Reality. Adapun empat elemen itu adalah sebagai berikut:

1) Virtual World, merupakan sebuah konten yang menciptakan dunia virtual dalam bentuk screenplay maupun script.

2) Immersion, merupakan sebuah sensasi yang membawa pengguna teknologi Virtual Reality merasakan ada di sebuah lingkungan nyata yang padahal fiktif. immersion dibagi dalam 3 jenis, yaitu:

a. Mental Immersion, membuat mental penggunanya merasa seperti berada di dalam lingkungan nyata.

b. Physical Immersion, membuat fisik penggunanya merasakan suasana di sekitar lingkungan yang diciptakan oleh Virtual Reality.

c. Mentally Immersed, memberikan sensai kepada penggunanya untuk larut dalam lingkungan yang dihasilkan Virtual Reality.

3) Sensory Feedback, berfungsi untuk menyampaikan informasi dari Virtual World ke indera penggunanya. Elemen ini mencakup visual (penglihatan), audio (pendengaran) dan sentuhan.

4) Interactivity yang bertugas untuk merespon aksi dari pengguna, sehingga pengguna dapat berinteraksi langsung dalam medan fiktif atau Virtual World.

Sebuah teknologi dapat dikatakan sebagai Virtual Reality jika sudah memenuhi persyaratan dimana tampilan gambar/grafis/visualisasi 3D tampak nyata dan sesuai dengan perspektif dari penggunanya, mampu mendeteksi semua gerakan dan respon dari pengguna, seperti gerakan kepala atau bola mata pengguna.

\subsection{Sejarah Perkembangan Virtual Reality}

Virtual Reality bermula dari sebuah prototype dari visi yang dibangun oleh Morton Heilig pata tahun 1962 yang bernama Senosorama dengan maksut untuk menghadirkan pengalaman menonton film agar tampak nyata dengan melibatkan berbagai indra berupa indra penglihatan, pendengaran, penciuman, dan sentuhan. Setelahi itu, Virtual Reality berkembang dari hari ke hari dan tentunya semakin canggih.

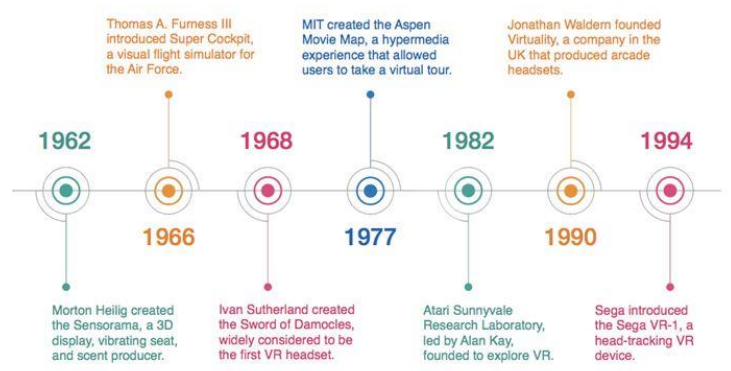

Gambar 2. Perkembangan Virtual Reality

Sumber: https://www.codepolitan.com

Gambar 2 menunjukkan perkembangan sejarah Virtual Reality mulai dari awal dikembangkan pada tahun 1962 hingga dikenalkan oleh Sega yang dinamai dengan Sega VR-1 pada tahun 1994. Tahun $2000 \mathrm{ke}$ atas Virtual Reality mengalami perubahan yang lebih canggih.

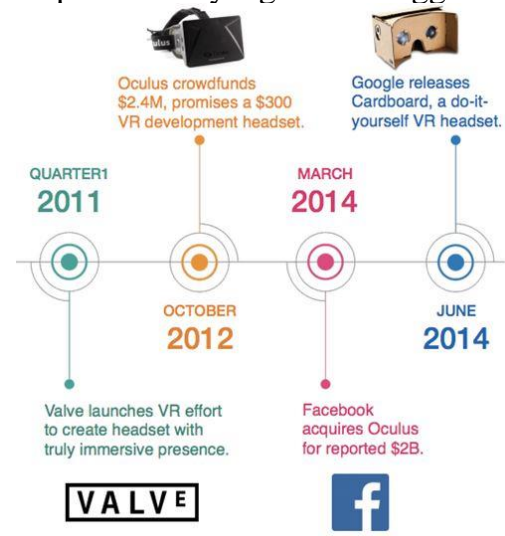

Gambar 3. Perkembangan Virtual Reality yang lebih canggih

Sumber: https://www.codepolitan.com 
Gambar 3 menunjukkan perkembangan teknologi Virtual Reality yang semakin canggih dengan diawali oleh Valve yang mengembangkan headset dengan menghadirkan immersive yang sebenarnya.

\subsection{Google VR SDK}

Google VR adalah teknologi di balik platform Google Daydream dan Google Cardboard VR. Google VR mencakup dukungan untuk smartphone, viewer dan pengontrol yang dipasang dipasang di kepala, tampilan dan aplikasi yang dipasang di kepala secara mandiri. Google VR menyediakan SDK untuk persatuan yang memungkinkan untuk membuat konten VR.

Teknologi Google VR mencakup Daydream, sebuah platform untuk $V R$ dan Cardboard berkualitas tinggi, dibangun untuk bite-size pengalaman $V R$ dan video 360. Daydream terdiri dari ponsel, headset, pengontrol, dan pengalaman yang siap digunakan daydream dan mendukung perangkat selular android kelas atas melalui daydream.
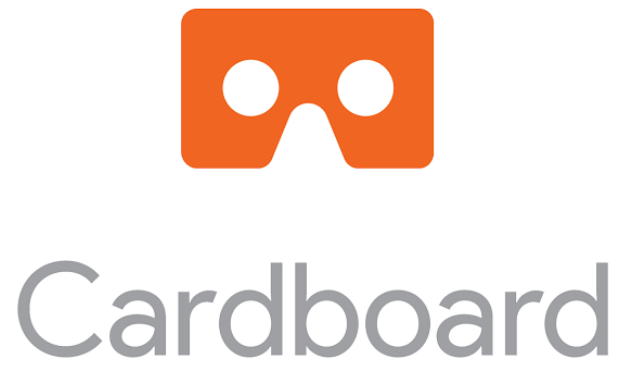

Gambar 4. Google Cardboard

Sumber: https://docs.unity3d.com

Google Cardboard merupakan solusi mobile $V R$ yang paling mudah diakses, memungkinkan siapa saja yang memiliki ponsel cerdas IOS atau android merasakan aplikasi VR. Cardboard memang memiliki persyaratan minimum dan yang disarankan untuk penggunanya, tetapi lebih sedikit terikat perangkat keras dari pada Daydream, terutama berfokus pada sistem operasi dan sitem kontrol dasar seperti giroskop. Pengguna dapat melihat aplikasi VR dengan perangkat tampilan Google Cardboard resmi atau perangkat tampilan perangkat VR pihak ketiga yang mendukung konten Google VR. Cardboard juga mendukung berbagai pengontrol genggam yang lain untuk aplikasi yang membutuhkan interaksi yang lebih kompleks.

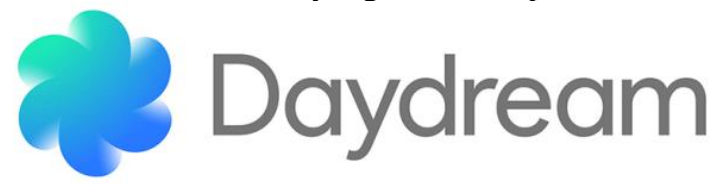

Gambar 5. Daydream

Sumber: https://docs.unity3d.com

Daydream memungkinkan pengalaman yang lebih kaya fitur daripada Cardboard, tetapi hanya mendukung perangkat yang siap Daydream, dibangun untuk $V R$ dengan tampilan resolusi tinggi, grafik halus dan sensor kepekaan tinggi untuk pelacakan head yang tepat. Aplikasi telepon Daydream dapat diakses dengan Daydream View, headset dan pengontrol gerak Google untuk pengalaman VR berkualitas tinggi, menggunakan smartphone yang siap menggunakan Daydream. Daydream juga akan mendukung Daydream Standalone HMD yang dibangun oleh produsen desain asli. Daydream Standalone adalah tampilan terpasang di kepala yang berjalan pada OS Android termasuk input pengontrol yang lebih kaya dan sensor gerak.

\subsection{Dino Park 3D}

Park dengan luas 1 hektar dengan teman zaman dinosaurus, berisi berbagai macam satwa prasejarah yang bisa dipelajari secara menyenangkan dengan pengkategorian yang memudahkan pengguna dalam dunia virtual. Berbagai macam satwa prasejarah siap untuk dipelajari dan pengguna akan dibawa berpetualang kembali ke masa jaya dinosaurus dan rasakan hidup bersama mereka di dunia virtual. Dino Park 3D adalah taman belajar dan wisata secara virtual untuk mengetahui bagaimana bentuk dari berbagai macam dinosaurus pada jaman prasejarah.

\section{Metode Penelitan}

Penelitian ini dikembangkan menggunakan Multimedia Development Life Cycle (MDLC) framework (Binanto, 2010) dengan implementasi model prototype.

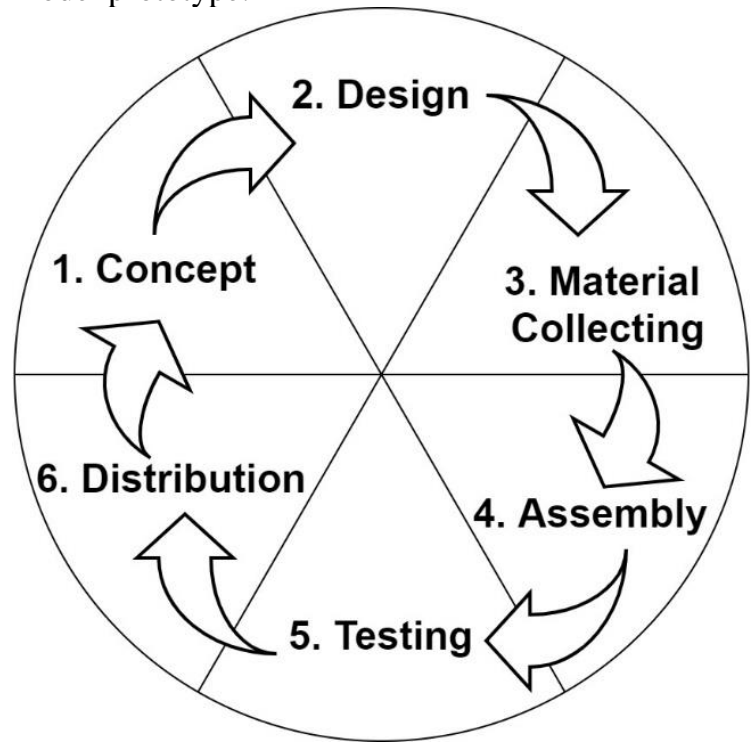

Gambar 6. Multimedia Development Life Cycle (MDLC)

Gambar 6 menunjukkan tahapan dari MDLC. MDLC terdiri dari tahapan yang masing-masing menghasilkan luaran untuk digunakan pada tahap selanjutnya. 


\section{A. Concept (Pengonsepan)}

Tahap ini adalah tahap untuk menentukan tujuan dan siapa pengguna program (identifikasi audiens). Tujuan dan penggunaan akhir program berpengaruh pada nuansa multimedia sebagai pencerminan dari identitas organisasi yang menginginkan informasi sampai pada pengguna akhir. Pada tahap ini dilakukan pengonsepan antara lain:

(1) Menentukan tujuan dan manfaat aplikasi Dino Park 3D berbasis Virtual Reality.

Tujuan dari aplikasi Dino Park 3D adalah mengembangkan sarana edukasi bagi pengguna tentang pengenalan hewan pada jaman prasejarah (dinosaurus) sehingga memberikan wahana edukasi baru untuk belajar tentang pengenalan hewan pada jaman prasejarah (dinosaurus) dalam dunia virtual.

(2) Menentukan siapa saja pengguna aplikasi Dino Park 3D berbasis Virtual Reality.

Penentuan obyek sebagai sasaran pengguna aplikasi bersdasarkan program pemerintah wajib belajar 9 tahun, sehingga target pengguna adalah siswa SD dan SMP sekaligus siswa SMA/SMK di dalamnya.

(3) Mendeskripsikan konsep aplikasi Dino Park 3D berbasis Virtual Reality yang akan dibangun.

Konsep yang diambil dalam menyusun aplikasi Dino Park 3D yaitu menggunakan konsep padang Sabana dimana terdapat sebuah padang rumput yang luas dan diselingi oleh beberapa jenis pohon yang tumbuh menyebar (seperti palm dan cemara), serta di dalam lingkungnan tersebut tersebar beberapa hewan purba (dinosaurus).

\section{B. Design (Perancangan)}

Pada tahap ini pembuatan spesifikasi mengenai rancangan dan arsitektur program dan bagiamana alur VR Dino Park yang akan dibuat berjalan. Selain itu, desain yang akan dibuat menggunakan desain interface Virtual Reality. Perangkat lunak yang digunakan untuk merancang interface adalah Unity 3D.

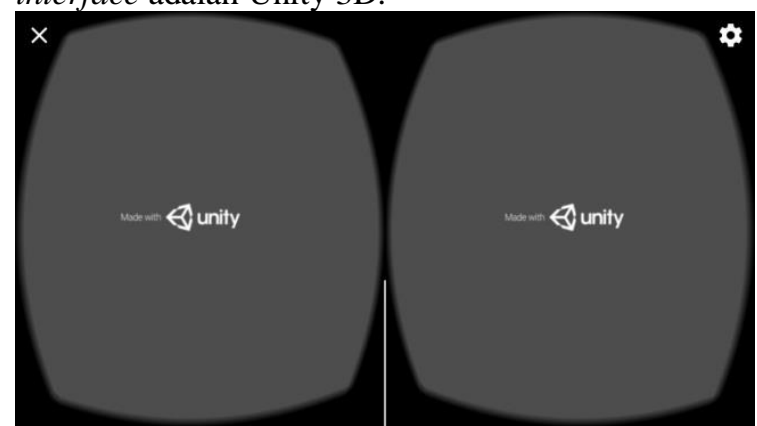

Gambar 7. Desain Tampilan Virtual Reality

Gambar 8 merupakan Activity Diagram dari VR Dino Park 3D.

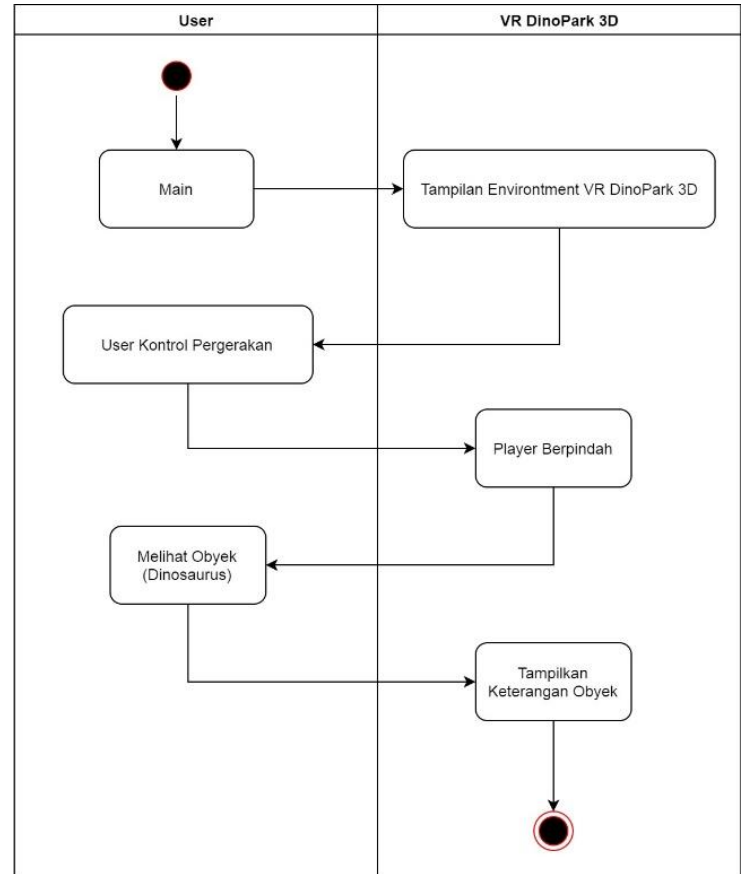

Gambar 8. Activity Diagram VR Dino Park 3D

\section{Material Collecting (Pengumpulan Bahan)}

Tahap ini adalah tahap pengumpulan bahan yang sesuai dengan kebutuhan yang dikerjakan. Bahan-bahan tersebut antara lain pemodelan 3D Dinosaurus, Terrain, ensiklopedia dinosaurus, sdk android, dubbing suara dan lain-lain. Tahap ini dapat dikerjakan secara parallel dengan tahap assembly.

Tabel 1. Model 3D Dinosaurus

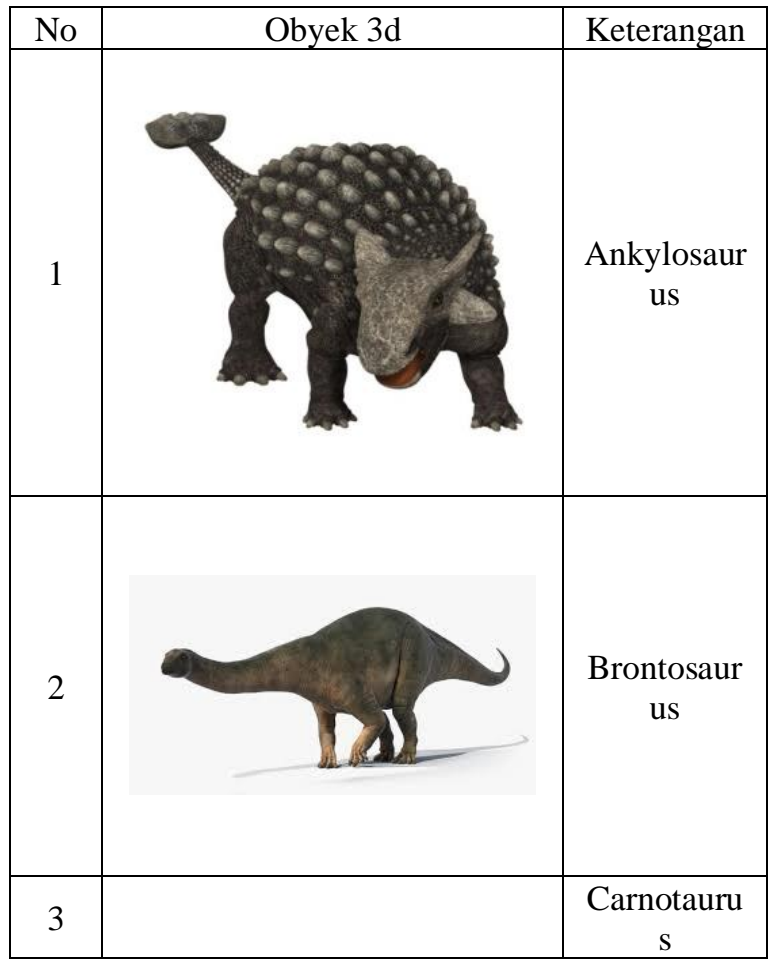




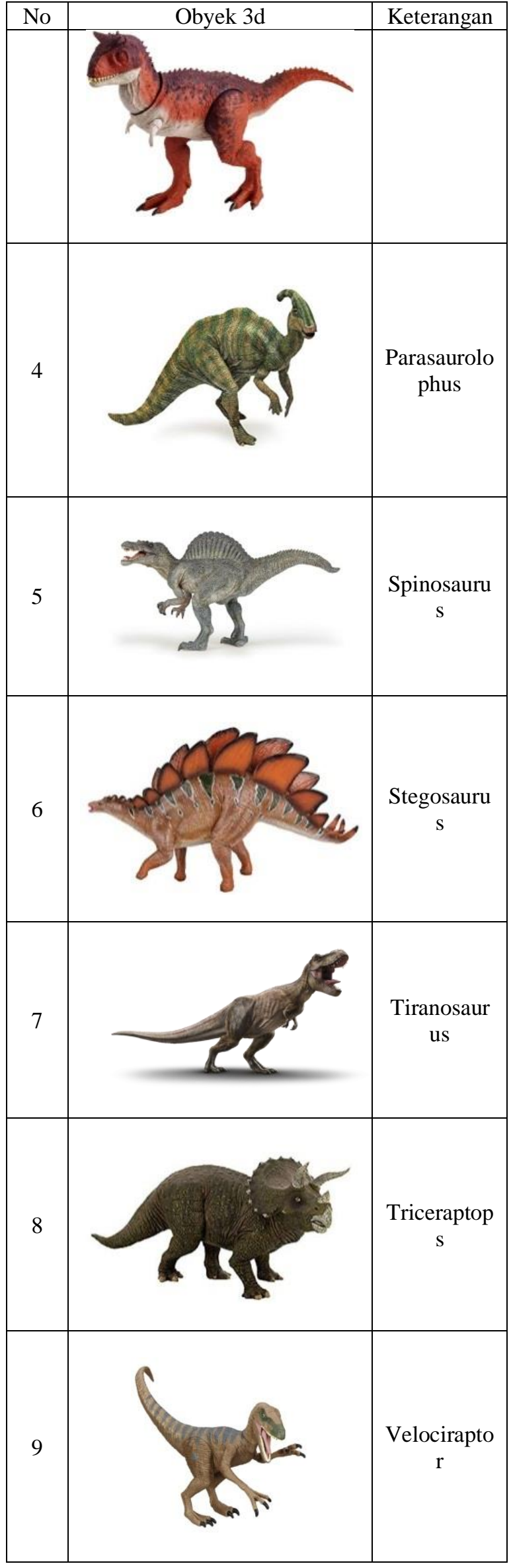

D. Assembly (Pemasangan)
Tahap assembly (pembuatan) adalah tahap penggabungan semua objek atau bahan multlimedia. Pembuatan apllikasi didasarkan pada tahap desain, seperti bagan alir dan/atau struktur navigasi. Pada tahap ini akan terbentuk sebuah lingkungan/environment Dino Park 3D yang dibuat dari penggabungan beberapa bahan yang telah dikumpulkan.

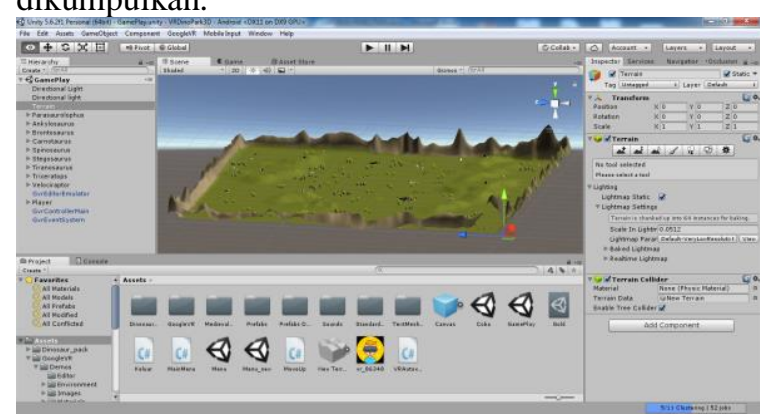

Gambar 9. Proses Assembly di Unity 3D

E. Testing (Pengujian)

Tahap testing (pengujian) dilakukan setelah menyelesaikan tahap pemasangan (assembly) dengan menjalankan aplikasi/program dan dilihat apakah ada kesalahan atau tidak. Tahap pertama pada tahap ini disebut juga sebagai tahap pengujian alpha (alpha test) yang pengujiannya dilakukan oleh pembuat atau lingkungan pembuatnya sendiri. Setelah lolos dari pengujian alpha, pengujian beta yang melibatkan pengguna untuk melakukan pengujian akhir.

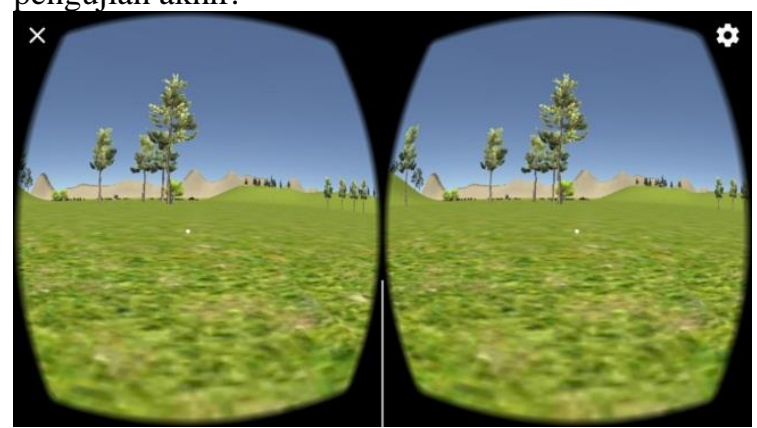

Gambar 11 Tampilan Awal

F. Distribution (Pendistribusian)

Tahap ini aplikasi akan dipasarkan dalam Google Play Store dalam bentuk apk yang siap diinstal pada smartphone berbasis android. Pengguna dapat malakukan download secara gratis pada masing-masing smartphone melalui Play Store https://play.google.com/store/apps/details?id=com.P 2KM.VRDinoPark3D. 
Volume 6, Edisi 4, Agustus 2020
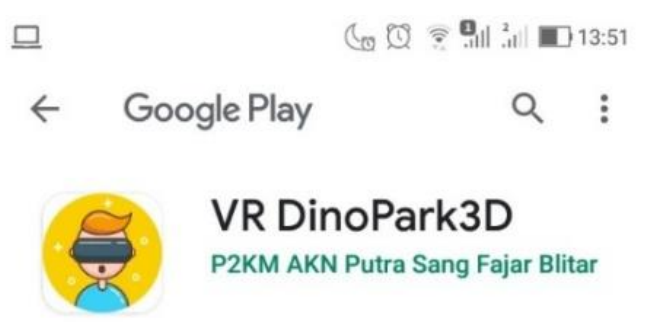

\section{VR DinoPark3D}

P2KM AKN Putra Sang Fajar Blitar
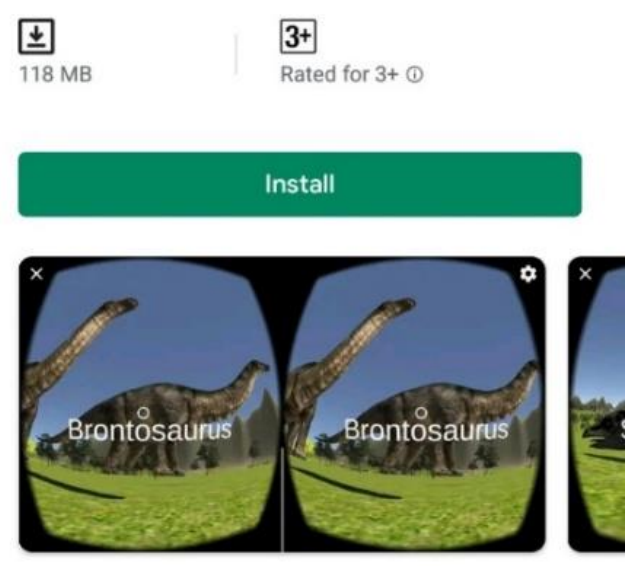

About this game

$\rightarrow$

Dino Park Virtual Reality 3 Dimensions

Adventure

Gambar 12. Publish Google Play

\section{Hasil dan Pembahasan}

Hasil dari penelitian ini telah menghasilkan aplikasi Dino Park $3 D$ berbasis Virtual Reality menggunakan Google VR SDK dengan lingkungan menggunakan konsep padang sabana dimana terdapat sebuah padang rumput yang luas dan diselingi oleh beberapa jenis pohon yang tumbuh menyebar (seperti palm dan cemara), serta di dalam lingkungnan tersebut tersebar beberapa hewan purba (dinosaurus).

Tabel 2. Pengujian Dino Park 3D

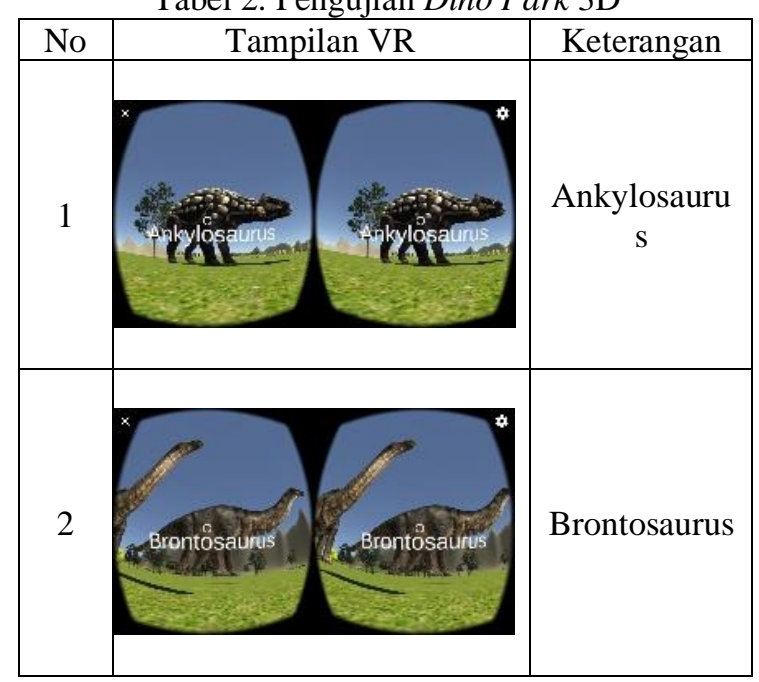

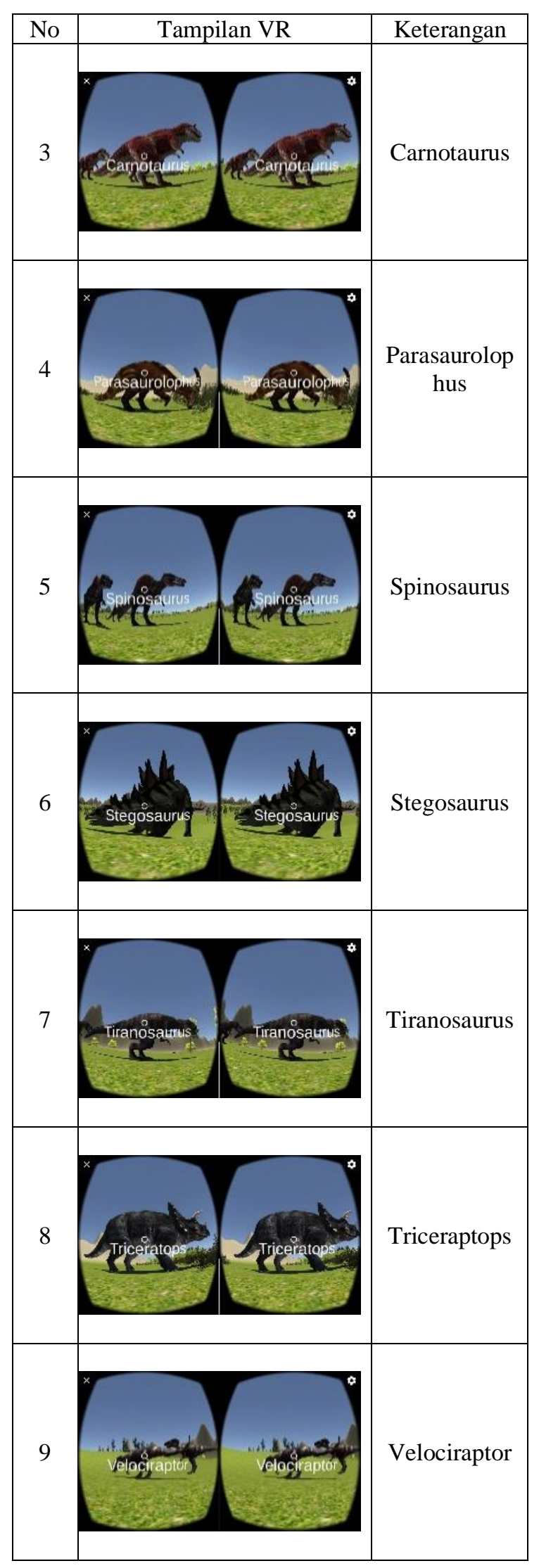

Untuk mendapatkan penilaian kesesuaian hasil aplikasi Dino Park 3D berbasis Virtual Reality menggunakan Google VR SDK maka dilakukan pengujian secara langsung dan membagikan 
kuisioner kepada 34 siswa jurusan Teknik Komputer dan Jaringan kelas 10 SMK Islam Blitar. Tabel 3 merupakan hasil rekapitulasi kuisioner dari uji coba aplikasi.

Tabel 3. Rekapitalasi Kuisioner Pengujian

\begin{tabular}{|c|l|c|c|c|c|}
\hline \multirow{2}{*}{ No } & \multirow{2}{*}{ Tampilan VR } & \multicolumn{2}{|c|}{$\begin{array}{c}\text { Kesesuain } \\
\text { Aplikasi }\end{array}$} & \multicolumn{2}{c|}{$\begin{array}{c}\text { Presentase } \\
\text { Kesesuaian }\end{array}$} \\
\cline { 3 - 6 } & & Ya & Tidak & Ya & Tidak \\
\hline 1 & Ankylosaurus & 34 & 0 & $100 \%$ & $0 \%$ \\
\hline 2 & Brontosaurus & 34 & 0 & $100 \%$ & $0 \%$ \\
\hline 3 & Carnotaurus & 34 & 0 & $100 \%$ & $0 \%$ \\
\hline 4 & Parasaurolophus & 34 & 0 & $100 \%$ & $0 \%$ \\
\hline 5 & Spinosaurus & 34 & 0 & $100 \%$ & $0 \%$ \\
\hline 6 & Stegosaurus & 34 & 0 & $100 \%$ & $0 \%$ \\
\hline 7 & Tiranosaurus & 34 & 0 & $100 \%$ & $0 \%$ \\
\hline 8 & Triceraptops & 34 & 0 & $100 \%$ & $0 \%$ \\
\hline 9 & Velociraptor & 34 & 0 & $100 \%$ & $0 \%$ \\
\hline & Rata-Rata & $\mathbf{3 4}$ & $\mathbf{0}$ & $\mathbf{1 0 0 \%}$ & $\mathbf{0 \%}$ \\
\hline
\end{tabular}

Melihat Tabel 3 dan mengacu pada metode pengembangan VRDino Park 3D menggunakan Google VR SDK dengan kerangka Multimedia Development Life Cycle (MDLC) framework pada tahap pengujian tampilan VRDinoPark 3D menghasilkan rata-rata tingkat kesesuaian program dan tampilan dengan nilai $100 \%$.

\section{Kesimpulan dan Saran}

Dengan mengacu pada metode MDLC framework dalam pengembangan aplikasi VR akan menjadi lebih terstruktur dari setiap tahapan yang dikerjakan. Selain itu hasil dari aplikasi ini juga bisa digunakan sebagai sarana edukasi bagi pengguna tentang pengenalan hewan pada jaman prasejarah (dinosaurus) sehingga memberikan wahana edukasi baru untuk belajar tentang pengenalan hewan pada jaman prasejarah (dinosaurus) dalam dunia virtual.

Untuk pengembangan penelitian selanjutnya aplikasi ini dapat dikombinasikan dengan perangkat Leap Motion sehingga user dapat mendapatkan pengalaman bermain dan interaksi dengan dunia virtual menjadi lebih nyata dan menyenangkan.

\section{Daftar Pustaka:}

Anonim (2019). Google VR SDK Overview https://docs.unity3d.com/2017.2/Documentation /Manual/VRDevices-GoogleVR.html. Diakses pada tanggal 1 Juli 2019.

Binanto, Iwan. 2010. Multimedia DasarDasar Teori dan Pengembangannya. Yogyakarta: ANDI.

Batson, Laura, \& Susan, F. (2006). Game Designs that Enhance Motivation and Learning for
Teenagers. Journal of Illinois Institue of Technology Electronic, 40.

Fuch, H., \& Bishop, G. (1992). NSF Invitational Workshop. Research Directions in Virtual Environments, 2.

Herman T.T.S. 2018. Teknologi Virtual Reality Untuk Media Informasi Kampus. Jurnal Teknologi Informasi dan Ilmu Komputer (JTIK). Vol. 6, No. 1: 71-76

J. Gregory. (2009). Game Engine Architecture, Wellesley MA: A K Peters Ltd., 2009.

Kresna Galuh D. Herlangga. 2016. Virtual Reality dan Perkembangannya. Tersedia pada: $<$ https://www.codepolitan.com/virtual-realitydan-perkembangannya> [Diakses pada tanggal 1 Juli 2019].

N. Llopis. (2010) "Game Architecture," in Introduction to Game Development, S. Rabin, Ed., Boston, Course Technology, Cengage Media, 2010, pp. 239-270.

Praja Irwandi. (2016). Perancangan Game First Person Shooter (FPS) "Boar Hunter" Berbasis Virtual Reality. Jurnal Rekursif. Vol. 4. No. 1.

Prensky, M. (2001). Fun, Play and Games: What Makes Games Engaging. Digital Game-Based Learning.

Rafiqa Maharani P.S. (2019). Rancang Bangun Virtual Reality Educational Game Penanggulangan Sampah berbasis Android untuk Anak Usia Sekolah Dasar (Development of Virtual Reality Educational Game on Waste Handling in Android Smartphone for Children). JUITA. Vol. VII.

R. J. Pagulayan, K. Keeker, D. Wixon, R. Romero and T. Fuller (2002), "User-centered design in Games," in Handbook for Human-Computer Interaction in Interactive Systems, Mahmah, $\mathrm{NJ}$, Lawrence Erlbaum Associates, 2002, pp. 883906.

R. T. Bakie. (2010). “Games and Society,” In Introduction to Game Development, 2nd ed., S. Rabin, Ed., Boston, MA, Charles River Media, 2010, pp. 43-58. 
Volume 6, Edisi 4, Agustus 2020

$\mathbf{5 4} \mid \mathrm{H}$ a 1 a $\mathrm{m}$ a $\mathrm{n}$ 